\title{
GCU
}

Glasgow Caledonian

University

University for the Common Good

\section{Construction and testing of self-drilled soil nails}

Mickovski, Slobodan B.; Lindsay, Fraser M.; Smith, Martyn J.

Published in:

Proceedings of the ICE: Geotechnical Engineering

DOI:

10.1680/jgeen. 15.00149

Publication date:

2016

Document Version

Author accepted manuscript

Link to publication in ResearchOnline

Citation for published version (Harvard):

Mickovski, SB, Lindsay, FM \& Smith, MJ 2016, 'Construction and testing of self-drilled soil nails', Proceedings of the ICE: Geotechnical Engineering, vol. 169, no. 6, pp. 541-553. https://doi.org/10.1680/jgeen.15.00149

\section{General rights}

Copyright and moral rights for the publications made accessible in the public portal are retained by the authors and/or other copyright owners and it is a condition of accessing publications that users recognise and abide by the legal requirements associated with these rights.

Take down policy

If you believe that this document breaches copyright please view our takedown policy at https://edshare.gcu.ac.uk/id/eprint/5179 for details of how to contact us. 
- Article type: paper

- Date text written: 30 May 2015

- Number of words: 5296 ; Number of tables: 2 ; Number of figures: 7.

Construction and Testing of Self-Drilled Soil Nails - a case study

Author 1 (corresponding author)

Dr Slobodan B. Mickovski, PhD, CEng, CSci, MICE, MCIWEM

Principal Geotechnical Engineer

Jacobs UK Ltd, Ground Engineering and Technology, Glasgow, Scotland

Current address: Reader in Civil Engineering, School of Engineering and Built Environment, Glasgow Caledonian University, Glasgow, Scotland

Tel: ++ 441412731105

e-mail: Slobodan.Mickovski@gcu.ac.uk

Author 2

Fraser M. Lindsay, MEng

Senior Geotechnical Engineer

Jacobs UK Ltd, Ground Engineering and Technology

95, Bothwell Street, Glasgow, Scotland

Tel: ++ 441412438753

e-mail: Fraser.Lindsay@jacobs.com

Author 3

Martyn J. Smith, M.Sc., C.Eng.,C.Geol., FIMMM, MHKIE, FGS

Director of Operations

Jacobs UK Ltd, Ground Engineering and Technology

95, Bothwell Street, Glasgow, Scotland

Tel: ++ 441412438554

e-mail: Martyn.Smith@jacobs.com 


\section{Abstract}

Current standards and best practice guidance recognise that testing of self-drilled hollow bar soil nails can be problematic as conventional packers and debonded lengths cannot be constructed. As a result, this provides difficulty in testing and confirming the ultimate bond resistance within the passive zone of a soil nailed slope, and thus the design soil nail lengths.

This paper provides a summary and review of the various testing procedures adopted for a soil nail construction project in Scotland. The practical design considerations, and their validation through the installation and testing of 49 sacrificial test nails, are detailed. The construction issues associated with the nail installation and testing are also outlined and discussed in the light of the results obtained using different testing approaches.

The aim of this case study is to report on the experiences with installation and testing of hollow bar soil nails. The objectives is to develop an initial data base of available soil-grout bond strength of hollow bar soil nails based on the several practical installation procedures used on this project and to establish areas for improvement of installation, testing and quality control in order to perform comparable pullout tests on self-drilled hollow bar soil nails.

\section{Keywords}

Geotechnical Engineering, Field testing and monitoring, Anchors and anchorages 


\section{Introduction}

Soil nailing is a form of slope stabilisation in which fully grouted steel or polymeric reinforcement bars are installed into the slope face of in situ ground, whether natural soil or existing fill, thus creating a reinforced block of soil. An appropriate facing system can then be constructed to stabilise the surface of the soil, thus completing the construction of the soil nailed slope. The use of soil nailing in slope stabilisation has grown rapidly in the UK since the mid-1990s (Phear et al, 2005).

Traditionally, soil nails comprise a solid steel tendon installed into a pre-drilled hole and then grouted. Self-drilled hollow bar soil nails have been developed relatively recently and offer significant advantages over the use of the traditional solid bar system (GEO, 2008) such as:

- $\quad$ installation into loose or collapsing soils without the need for casing to support the drill hole using the grout as a drilling fluid, and

- $\quad$ increased nail capacity due to the grout permeating the adjacent soil and increasing the bond diameter, both of which lead to increase in production rates and time savings for the contractor (Porterfield et al 1994, Phear, 2005, GEO, 2008).

This system allows relatively small lightweight rigs to be able to install the soil nails within most ground conditions much quicker than the traditional construction method, which not only reduces the construction time and the overall cost of the system, but also reduces the health and safety implications of mobilising heavy plant to an already failed or unstable slope. Conversely, the disadvantages of such a system include:

- $\quad$ a need for proper controls of grout flush to ensure integrity of bond length, i.e. problematic in voided or very loose ground,

- $\quad$ a requirement for more attention to workmanship and supervision to ensure that the quality of the constructed nails does not suffer and

- difficulties in pull-out testing if use of the hollow bar system is attempted for testing which is considered in this paper.

Depending on the objectives, various forms of soil nail testing can be specified Design investigation testing can be undertaken prior to the soil nail design in order to ascertain the ultimate bond resistance of each stratum, its variability with depth, and the potential influence of groundwater on the bond resistance (i.e. testing within the same soil stratum above and below the groundwater table). In this type of test, a sacrificial test nail is constructed with a specified bonded length and is subsequently tested to failure using load test equipment appropriate for anticipated loads and bond resistances (Lazarte et al 2003; Phear et al 2005). Suitability (pullout) testing is traditionally undertaken immediately prior to or during the soil nail construction works to verify the ultimate nail pullout capacity assumed in the design and, thus, the soil nail lengths. These tests require construction of sacrificial test nails with a specified bonded length which is typically (Phear et al., 2005) achieved by partial grouting of the distal 
end of the drill hole in order to mimic the length of the nail within the passive zone of the slope which is determined within the design. The pull-out load applied to the test nail should equal the working load determined within the design, multiplied by a partial factor typically in the range of 1.5-2.0 (Phear et al., 2005; BS 8006-2, 2011). An acceptable test, thus verifying the soil nail lengths determined within the design, is where the creep rate at the pull-out load is less than $0.1 \%$ of the bond length of the test, often $2 \mathrm{~mm}$ per log cycle of time (Phear et al., 2005; BS $8006-2,2011$ ) as the test length is often the lower $2 m$ of the nail (GEO 2008). Acceptance testing can be undertaken on working nails to demonstrate satisfactory soil nail performance at the design load. This test is undertaken on fully grouted production soil nails and is not suitable to verify the lengths determined within the design or confirm the ultimate bond resistance of any strata. This type of test is primarily to confirm that the installation methods give satisfactory displacement results at the working load and is not discussed further in this study.

For both pullout (suitability) and design investigation tests the successful formation of the bonded length is critical (Richards 2010, Gomez 2008). With solid bars, the drill hole is formed using 'open hole' techniques (Phear et al 2005) and progressed to the base of the bonded length before a steel bar is inserted and grouted to a specified length of the distal end of the hole (bonded length, Figure 1), with a packer or bond isolator and a debonding sleeve installed to retain the grout (debonded length, Figure 1); However, this technique is not suited for selfdrilled soil nails as, by their very nature, their installation does not allow packers and debonded lengths to be constructed (Cadden et al 2010), and alternative methods of installation or testing have to be sought (Phear et al 2005). The introduction of BS EN 14490 in 2010 and the code of practice for soil nail design (BS 8006-2) in 2011 do not provide any clarity on how testing of selfdrilled soil nails should be undertaken, and rely on the designer's knowledge and experience of the ground conditions at the site (Richards 2010, Littlejohn and Bruce 1977) and the impact on the soil nail construction and testing to confirm the test procedure to satisfy the design assumptions.

Published literature (Phear et al 2005, Cadden et al 2010, Lazarte 2011) suggests subtracting the pullout capacity of a fully grouted test nail installed in the active zone from the pullout capacity of a fully grouted test nail installed to the specified design length which would give the pullout capacity of the bonded length within the passive zone. This solution is promoted as the most effective for testing hollow bar self-drilled soil nails based on the experience of the specialist supply and testing contractors (DSI 2008). This technique can be misleading especially where longer nails are used with nails passing through different soil strata and most of the current design methods require bond stress data for each stratum.

The aim of this case study is to report on the experiences with installation and testing of hollow bar soil nails, investigating the effects on the optimisation of the design. The objectives are to analyse case study data in order to determine the characteristic grout-soil bond strength to be 
used to verify the design, to analyse the test nail construction considerations and effects such as productivity, and to raise awareness of the need for standardised testing approach with designers and contractors.

\section{Methodology}

\subsection{Site description}

Self-drilled hollow bar soil nails were used in a recent slope stabilisation project in Scotland. The site in Stonehaven is predominately located around the former trunk road (Bervie Braes Road), and includes the adjacent coastal slope (Bervie Braes). The 40m high coastal slope in Stonehaven has a history of instability (typical mechanisms include failures within the weak near surface soils combined with occasional shallow groundwater, or perched water at times of heavy rainfall, and over-steepened ground profiles; Currie et al 2009) which has resulted in the closure of the former trunk road bisecting the slope. The road runs sidelong and generally northwest-southeast across the Braes. The slope stabilisation works were limited to the slope below the road ('Lower slope' on Figure 2a; Mickovski 2014b).

The angle of the lower slope ranges between $25^{\circ}$ and $30^{\circ}$, while the upper slope angle varies between $30^{\circ}$ and $35^{\circ}$. Ground investigations (Currie et al 2009) showed that the soil on the lower slope typically consisted of vegetated topsoil (around $0.2 \mathrm{~m}$ thick), overlying Raised Beach Deposits comprising weak silts and silty sand with discrete soft cohesive layers with thickness ranging from $1.5 \mathrm{~m}$ to $5.0 \mathrm{~m}$. This stratum is underlain by medium dense glacial sands and stiff cohesive Glacial Till with thickness of up to $20 \mathrm{~m}$ which, in turn, overlies the sandstone bedrock (Figure 2b).

The groundwater regime within the Braes consists of a shallow perched groundwater table which exists due to the presence of the discrete cohesive layers within the Raised Beach Deposits. A deeper groundwater table is present perched upon the stiff cohesive Glacial Till (Mickovski 2014b).

\subsection{Soil Nail Design}

Soil nailing, as means of improving the safety of the slope against failure, was the preferred method of stabilisation selected after public consultation between the Local Authority and the local residents following an options assessment (Currie et al 2009). Self-drilled hollow bar soil nails were preferred to solid bar soil nails given the perceived associated lower construction costs (mainly savings in construction time, Samtani and Nowatzki, 2006) and the limited budget available for the works (Mickovski et al 2013, Mickovski 2014b).

The soil nails were designed in general accordance with CIRIA guidance (Phear et al, 2005; prior to BS 8006-2 (2011)), specifically using the effective stress method (Method 4) detailed therein, considering the expected ground conditions at the site and the available information. 
The design load for each soil nail was determined based on the pullout resistance of the nailgrout continuum from the soil and the working loads were determined by factoring the ultimate pullout load with an appropriate factor of safety. Soil nail lengths of between $7 \mathrm{~m}$ and $24 \mathrm{~m}$, placed at $1.5 \mathrm{~m}$ horizontal and $1.0 \mathrm{~m}$ vertical spacing, were required to provide the necessary resistance to shallow and deep seated (active zone of up to $10 \mathrm{~m}$ depth) slope failures.

A 'soft facing', consisting of a buried reinforced concrete soil nail head, bio-degradable matting, and a light metallic mesh, was selected given the site conditions and the project aesthetic requirements (Mickovski et al 2013, Mickovski 2014a). The concrete nail head, designed to DMRB HA 68/94, was envisaged to provide long term stability of the slope by transfer of the soil load back to the soil nails bond length and also to provide shallow surface stability between the nails. The bio-degradable jute mat and a light metallic mesh formed part of the facing to help prevent surface erosion and support establishment of vegetation which, in turn, would provide resilience of the structure in the long term (Norris et al. 2008, Mickovski 2014a,b).

\subsection{Construction and testing}

Sacrificial test nails (BS14490:2010), were evenly distributed throughout the lower slope to verify the design assumptions (e.g. bond strength, pullout capacity) and assess nail performance across the site. All test nails in this study comprised a $38 \mathrm{~mm}$ external and $19 \mathrm{~mm}$ internal diameter ( $753 \mathrm{~mm}^{2}$ cross-sectional area), galvanised steel bars in $3 \mathrm{~m}$ long sections, ,coupled together using galvanised steel couplers to achieve the design length and progressed using a sacrificial bit drilling a $100 \mathrm{~mm}$ diameter hole. The access to the test nail locations was cleared of vegetation and the drilling rigs were positioned at each location ensuring the safety and stability would be maintained during the construction (Figure 3). The nails were tested by application of pullout load in stages (BS14490:2010, Phear 2005; GEO 2008) either until either the required pullout resistance or the design yield strength of the bar was reached. Test failure was defined as the pullout load at which either (i) the creep movement $(>0.1 \mathrm{~mm})$ continues after a one hour hold period or (ii) the total movement exceeded $0.1 \%$ of the bonded length of the bar (Phear 2005).

\subsubsection{Long Nail / Short Nail (LN/SN) test}

With solid bar installation the normal procedure is to form the borehole using normal drilling with water or air-foam or similar, then insert the bar and grout up the distal end (ground anchor) or the full length (soil nail). No other area of the bar is grouted or in contact with the surrounding soil, as it is the working bond between the soil and grout that provides the pull-out resistance and thus stabilising the slope. The hollow bar nails generally use grout as a flushing medium which may cause difficulties for testing because, even if a debonding sleeve over the free length is used, grout will exist both inside and outside the sleeve and bar couplers may well be bigger than the available sleeve, preventing pull-out movement during the test. To over-come these difficulties, a 'long nail / short nail' test method was initially adopted in accordance with 
published guidance (Phear et al 2005) and the contractor method statement based on recommendations from a specialist testing sub-contractor (DSI, 2008). A total of 56 nails (more than $3 \%$ of the number of permanent nails; Phear et al 2005) were installed using an Atlas Copco ROC 460 rig into the Raised Beach Deposits, Glacial Till and Gravels. The 28 short nails (Figure 4) were installed using air flush due to high groundwater to the boundary between the active and passive zones, as determined within the design, and the remaining 28 long nails, reflecting the design length of the working nails at each location, were installed using air flush to full design depth thus allowing the bond resistance from the passive zone alone to be theoretically determined from pullout tests as:

\section{Bond resistance from the passive zone = pullout resistance of the long nail - pullout resistance of the short nail}

The pullout load of the short nail in the pair was added to the design load of the long nail before the long nail was tested for pullout under this new, combined load. It should be noted that the active and passive zones are functions of particular limit equilibrium analyses and the key issue during testing (BS 14490:2010) was to de-bond the heads of the nails $1 \mathrm{~m}$ from the reaction frame to ensure that local boundary effects did not result in overestimating the bond strength.

\subsubsection{Investigation Tests}

Additional test nails (ATNs) were installed to a variety of depths within the Glacial Till in the areas where the testing of the initial short nail / long nail system proved inconclusive or where the tested nails failed in pullout. Fourteen ATNs, installed using the same rig as in SN/LN test, were progressed using water flush to the full design depth before a set volume of grout was pumped into the open hole, grouting a known bonded length. The test load was derived as the design load multiplied by a factor of safety of 1.5 (BS14490:2010)

Another seven nails were drilled using a KLEMM KR904 rig to a variety of depths in the Glacial Till, where the majority of the design bond lengths are located. The holes were progressed using water flush and casing through the Raised Beach Deposits and Glacial Sands and Gravels before the nail bars were then inserted to full depth and a known volume of grout was pumped into each of the holes. This rig was used for this purpose because of its capability to case and control the size of the bore and volume of grout pumped.

The aim of the investigation tests was to determine the bond resistance per metre length of the bonding strata thus a shorter bond length was required to ensure that the nail would pull out and therefore provide a result. All 21 investigation nails were tested to failure (defined as in LN/SN test) such that the ultimate bond resistance of the Glacial Till per metre run could be determined and compared to the results of LN/SN test when verifying the design. 


\section{Results}

\subsection{Installation}

Test preparation included excavating a bench into the slope cleared of vegetation which, due to the size of the reaction frame which was dependent on the expected loads, involved excavation of approximately $2 \mathrm{~m}^{3} /$ nail. This excavation was carried out for each nail which, in the case of LN/SN setup where both nails are installed at close proximity, involved sizeable localised excavation. The size of the excavation was exacerbated by the slope angle and the inclination of the nail which meant the bench cut in the slope had to be at $70^{\circ}$.

After the test location was prepared, the drilling rig was secured in place and the nails were installed as per Section 2.3. The nail installation time ranged between 14 and 75 minutes for the LN/SN nails and ATNs, and was approximately 6 minutes for the KLEMM nails.

Due to the size and the weight of the reaction frame, which depended on the test loads which, in turn, depended on the chosen test method, the transportation to and from each test location across the slope was difficult, involved a combination of manual and plant labour, and lasted between 20 and 60 minutes depending on the transport distance and location on the slope.

\subsection{Testing}

The pullout tests were carried out using standard () testing equipment (BS14490:2010, Phear 2005) including a 400 kN capacity, 200 mm diameter, hydraulic jack and displacement transducers with $0.01 \mathrm{~mm}$ precision (Figure 5). The test duration was dependent on the pullout load and it ranged between 25 minutes (failure recorded at relatively low loads) and 175 minutes (design yield load for the steel bar reached) per nail. The total nail testing duration on the project was 60 days which included installation, setup and pullout testing.

\subsection{Test results}

Fifty-three of the 56 (28 pairs) nails installed using the SN/LN method were tested and the results are shown in Table 1. Typical pullout behaviour of a pair of long and short nails is shown on Figure 6a. It can be seen that satisfactory results on the nail resistance to pullout in relation to the design load were obtained for $49 \%$ of the installed (26 nails, 13 pairs). The results of the testing were termed 'inconclusive' where the short nail pulled out at a higher load than the long nail, short nail pulled out at a relatively high load in relation to the design yield strength of the steel bar, or where the long nail failed and the short nail did not. In all of these cases (9 nail pairs or $33 \%$ of the total tested) the nails did not fail in pullout but, due to the nature of the tests, the interpretation of the results was difficult. Five nail pairs failed because the difference between the pullout resistance of long and short nail was lower than the design load. 
Table 1. Results of the pullout tests on LN/SN testing system. The resistance to pullout of the grouted short nail length is subtracted from the one of the long nail to derive the resistance of the bonded length. Remarks: N/A and $\left(^{*}\right)$ denote inconclusive tests where the short nail pulled out at a higher load than the long nail or short nail pulled out at a relatively high load in relation to the design yield strength of the steel bar i.e. where the interpretation of the result was difficult due to the nature of the test; $\left.{ }^{* *}\right)$ denotes design verification failure. GSG = Glacial Sands and Gravels, $\mathrm{GT}=$ Glacial Till .

\begin{tabular}{|c|c|c|c|c|c|c|c|}
\hline Test nail & $\begin{array}{c}\text { Grouted } \\
\text { length of } \\
\text { short nail } \\
{[\mathrm{m}]}\end{array}$ & $\begin{array}{l}\text { Pullout } \\
\text { resistance } \\
\text { of short } \\
\text { nail }[k N]\end{array}$ & $\begin{array}{c}\text { Additional } \\
\text { grouted } \\
\text { length of } \\
\text { long nail } \\
\text { [m] }\end{array}$ & $\begin{array}{c}\text { Pullout } \\
\text { resistance } \\
\text { of long nail } \\
{[\mathrm{kN}]}\end{array}$ & $\begin{array}{c}\text { Pullout } \\
\text { resistance } \\
\text { of bonded } \\
\text { length [kN] }\end{array}$ & $\begin{array}{l}\text { Bonding } \\
\text { Strata }\end{array}$ & Remarks \\
\hline TN11 & 8.8 & 340 & 11.2 & not tested & & GSG \& GT & $\mathrm{N} / \mathrm{A}$ \\
\hline TN13 & 7.6 & 310 & 9.4 & 360 & 50 & GSG \& GT & $\star \star$ \\
\hline TN14 & 8.6 & 210 & 11.4 & 360 & 150 & GSG \& GT & * \\
\hline TN15 & 8.2 & 100 & 11.8 & 160 & 60 & GSG \& GT & $* \star$ \\
\hline TN16 & 8 & 290 & 10 & 350 & 60 & GSG \& GT & ** \\
\hline TN17 & 8.6 & 90 & 11.4 & 250 & 160 & GSG \& GT & \\
\hline TN18 & 12.2 & 290 & 11.8 & not tested & & GT & $\mathrm{N} / \mathrm{A}$ \\
\hline TN19 & 13 & 260 & 11 & 140 & & GSG \& GT & $\star \star$ \\
\hline TN20 & 10 & 150 & 14 & 310 & 160 & GT & \\
\hline TN21 & 11.8 & 300 & 12.2 & 280 & & GT & ** \\
\hline TN22 & 9.2 & 360 & 8.8 & 360 & & GSG \& GT & * \\
\hline TN23 & 11.2 & 190 & 12.8 & 340 & 150 & GT & \\
\hline TN24 & 12.4 & 290 & 11.6 & 360 & 70 & GSG \& GT & * \\
\hline TN34 & 10 & 80 & 2 & 350 & 270 & GT & \\
\hline TN35 & 5.25 & 40 & 4.75 & 360 & 320 & GSG & \\
\hline TN25 & 6 & 220 & 9 & 360 & 140 & GT & * \\
\hline TN26 & 10 & 360 & 2 & 360 & & GT & * \\
\hline TN28 & 10 & 360 & 2 & not tested & & GT & $\mathrm{N} / \mathrm{A}$ \\
\hline TN29 & 3 & 30 & 7 & 130 & 100 & GT & \\
\hline TN31 & 6 & 80 & 9 & 360 & 280 & GT & * \\
\hline TN32 & 4 & 130 & 6 & 180 & 50 & GSS \& GT & \\
\hline TN51 & 9 & 30 & 2 & 190 & 160 & GSG \& GT & \\
\hline TN52 & 9 & 80 & 2 & 120 & 40 & GT & $* *$ \\
\hline TN53 & 5.5 & 70 & 1.5 & 170 & 100 & GSG & \\
\hline TN54 & 9 & 140 & 2 & 250 & 110 & GT & \\
\hline TN55 & 5.25 & 40 & 1.75 & 110 & 70 & GSG & \\
\hline TN56 & 9 & 130 & 2 & 290 & 160 & GSG \& GT & \\
\hline TN57 & 5 & 70 & 2 & 120 & 50 & GSG & \\
\hline
\end{tabular}

The results of the investigation tests carried out to clarify the inconclusive results of the SN/LN tests are shown in Table 2. Typical behaviour of different types of additional test nails is shown on Figure $6 b$. 
Table 2 Results of the investigation tests. Remarks: $(*)$ denotes inconclusive tests where the design load $\leq$ pullout load $\leq$ combined test load, i.e. where the interpretation of the result was difficult due to the nature of the test; $(* *)$ denotes design verification failure. GSG = Glacial Sands and Gravels, GT = Glacial Till.

\begin{tabular}{|c|c|c|c|c|c|c|}
\hline Test nail & $\begin{array}{l}\text { Installed } \\
\text { length } \\
{[\mathrm{m}]}\end{array}$ & $\begin{array}{l}\text { Bonded } \\
\text { length } \\
{[\mathrm{m}]}\end{array}$ & $\begin{array}{l}\text { Failure } \\
\text { Load [kN] }\end{array}$ & $\begin{array}{l}\text { Design } \\
\text { Verification } \\
\text { Load (kN) } \\
\end{array}$ & $\begin{array}{l}\text { Bonding } \\
\text { Strata }\end{array}$ & Remarks \\
\hline TN12 & 20 & 5.5 & 120 & 180 & GSG \& GT & * \\
\hline ATN10 & 20 & 9.7 & 155 & 155 & GSG \& GT & \\
\hline ATN11 & 20 & 9.7 & 230 & 165 & GSG \& GT & \\
\hline ATN12 & 20 & 9.7 & 150 & 150 & GSG \& GT & \\
\hline ATN14 & 20 & 5.5 & 70 & 180 & GSG \& GT & ** \\
\hline ATN5 & 13.5 & 5.5 & 220 & 195 & GT & \\
\hline ATN7 & 24 & 8.3 & 140 & 195 & GT & * \\
\hline ATN8 & 15 & 8.3 & 300 & 130 & GSG \& GT & \\
\hline ATN13 & 24 & 6.9 & 210 & 205 & GSG \& GT & \\
\hline TN27 & 15 & 2.8 & 55 & 80 & GT & * \\
\hline TN30 & 15 & 2.8 & 45 & 80 & GT & ** \\
\hline ATN1 & 12 & 5.5 & 70 & 70 & GT & \\
\hline ATN3 & 15 & 2.8 & 35 & 110 & GT & *夫 \\
\hline ATN9 & 11 & 7.5 & 220 & 60 & GT & \\
\hline KLEMM1 & 24 & 5.5 & 70 & $\mathrm{~N} / \mathrm{A}$ & GT & \\
\hline KLEMM2 & 24 & 5.5 & 80 & $\mathrm{~N} / \mathrm{A}$ & GT & \\
\hline KLEMM3 & 24 & 6.9 & 110 & $\mathrm{~N} / \mathrm{A}$ & GT & \\
\hline KLEMM4 & 21 & 2 & 190 & $\mathrm{~N} / \mathrm{A}$ & GT & \\
\hline KLEMM5 & 18 & 2 & 80 & N/A & GT & \\
\hline KLEMM6 & 15 & 2 & 90 & $\mathrm{~N} / \mathrm{A}$ & GT & \\
\hline KLEMM7 & 12 & 2 & 80 & N/A & GT & \\
\hline
\end{tabular}

It can be seen that satisfactory results on the nail resistance to pullout in relation to the design load were obtained for $57 \%$ of the installed ATNs. The results of the testing were inconclusive in $21 \%$ of the ATNs where the nail pulled out at a higher load than the design load but lower than the combined test load. The remaining 3 ATNs failed as their resistance pullout was lower than the design load. However, it should be noted that the bonded length of the failed nails was shorter than the design bonded length and the potential resistance of the full design bonded length was calculated as the product of the bond resistance per metre length from the tests and the length of the design bond.

\section{Discussion}

The results of this study showed similarities and differences between the methods, as well as between this case study and the published literature. While the general installation of the test nails was very similar between the methods used in this case study (the difference being the use of different flush material), the success of the specific installation method depended on the 
ease of access and health and safety considerations. Test nail installation with each rig type included disturbance of the slope and the superficial soil deposits in terms of rig access and establishment of safe system of work. The access with the lightweight rig was more flexible as the rig could be positioned almost precisely on the desired location although this was done at the cost of damage to the existing vegetation and exacerbated erosion due to trampling during setup and installation. The heavier KLEMM rig could not operate on the slope and required much more elaborate and robust safety system. Only relatively light rigs could operate on a long slope where long reach or heavier rigs reported in the literature (Cadden et al 2010) could not be used, but these rigs have a limitation with depth that can be reached and type of soil strata that can be penetrated. The designer needs to consider the access to test nail locations and balance the testing schedule against the potential outcomes of the testing. Furthermore, the designer needs to consider the health and safety implications of specifying different tests and, in this respect, the LN/SN method may be further unsuitable due to the need for manual excavation and handling of heavier equipment.

In terms of test nail installation technique, air flush was considered to create voids within the soil which then get easily filled with grout and contribute towards 'bulbing' which, while beneficial for the overall nail capacity (Cadden 2010, Lazarte 2011), creates problems for pullout testing of fully grouted longer nails (e.g. higher pullout capacity necessitating heavier testing equipment and more slope disturbance). That is why water flush was used for the ATNs and KLEMMs that only aimed at determination of pullout capacity per specified bonded length, but the efficiency of this technique could not be assessed with certainty because the bonded lengths in these cases were shorter than those used in long/short nail pairs in order to limit the slope disturbance and heavy testing equipment. Grout flush could not be used to grout distal parts of the test nail only because of the issues noted in Section 2.3.1, i.e. the alternative methods, as postulated by Phear (2005), were used to produce a hole for soil nail bar to be grouted along bonded length only. Problems arising from drilling with water flush in areas of high groundwater tables would be envisaged and further research is needed in assessing the efficiency of different installation types in different soil types.

Current codes and testing guidance rarely cover the testing preparation which includes benching into the slope and setting up the reaction frame. In this case study this element was one of the most time consuming and disruptive to the soil on the slope. The excavation for the reaction frame and the associated backfill were significant and, due to the length and access constraints on the slope, had to be carried out in large part manually. This approach worked relatively well on the shallow natural slope in this case study but may be an issue on steeper slopes with soft soils, high groundwater level and/or failures occurring when access and excavation angles would be limited and temporary support may be needed. More attention will have to be paid on this aspect of test nail installation in the future as part of the overall nail 
testing methodology. It may be necessary to design and specify tests that would require minimum excavation and produce minimum disturbance to the soil on the slope.

The results of the testing methods used showed large percentage of inconclusive results and a small number offailures of design verification due to the testing method (including the testing setup) adopted by the contractor, which may have not been suitable for the encountered ground conditions (e.g. high groundwater and saturation). The calculated pullout stress based on the tests carried out (Figure 7) shows, however, similar trends and values across the different methods.

The values obtained in the tests correspond to the values reported in the literature for drilled nails (Lazarte et al 2003, Phear et al. 2005, Littlejohn and Bruce 1977, Porterfield et al 1994), albeit the published results do not distinguish between self-drilled and traditionally installed nails. It should be noted that the values shown correspond to average interpreted bond strength along the bond length of the nail, and may not be representative of larger, localized values within the bonded zone (Littlejohn and Bruce 1977, Cadden et al 2010). As reported in the literature (Phear et al 2005, Lazarte et al 2003), shorter and relatively stiffer soil nails showed higher pullout resistance per metre bonded length than the longer, more flexible nails. It is likely that this is the result of a simultaneous mobilisation of bond strength along the entire length of the short nail as opposed to progressive mobilisation of soil-grout shear strength in the longer nails (Frank and Zhao 1982, Gomez et al 2008) which leads to lower average bond strength in identical soil formations.

The ATN method of installation contains assumptions on the installation such as forming the bond length into an entirely homogenous material with a high proportion of grout dissipating into the surrounding soil (DSI 2008). Given the fact that the majority of the nails in this case study were designed for a bonded length in Glacial Till, it was not likely that a high percentage of the pumped grout would dissipate into the surrounding soil. The ATN grouted lengths quoted in Table 2, have been determined by calculation assuming no dissipation of grout in the Glacial Till (i.e. the bonded portion of the nail is a cylinder with a diameter equal to the bore diameter and height equal to the bonded length of the nail) by means of which it was assured that a conservative assessment of bond resistance is made.

A comparison of the resistance of the bonded length back-calculated using a conservative estimate of the pullout resistance (40 kPa, Figure 7), with the design bond resistance shows a margin of safety of between 1.08 and 2.68 for all additional nails (ATNs and KLEMMs). This justifies the design, bearing in mind that partial factors of safety (BS EN 1991, 2009; BS EN 1997-1, 2007) were used to derive the design bond resistance but also shows that the utilisation factor may be very low for a relatively large number of nails. If the Eurocode 7 (BS EN 1997-1, 2007) philosophy is used and the design is based and optimised through testing verification, it 
may be more cost effective to carry out design verification tests on production nails using conservative estimate of the bond resistance from case studies or published research which would have to be developed for self-drilled hollow bar nails. However, it should be noted that both our and values in the literature correspond to the undrained bond strength which is higher than the effective bond strength during the service life of the nail (Phear et al 2005). Further research will be focussed on the comparison of the measured bond strength and the design bond strength in order to define a realistic partial factor of safety.

The experience during this case study was that the specifics of nail installation and testing depended on the testing loads which ultimately depended on the adopted testing method. The higher testing loads due to long, fully grouted nails necessitated larger excavation for a larger testing rig as well as longer time for testing and more robust safe method of working. The risk of inconclusive tests was also higher due to potential 'bulbing' (Cadden et al 2010) and interaction between short and long nails installed relatively closely together. The longer testing time meant prolonged exposure of the excavated soil to the elements and trampling leading to erosion. Longer tests posed a risk of slowing down the progress of the production nails and verification and optimisation of the design where it was based on the results from testing (Murray 1993).

It is considered that pull-out testing using sacrificial solid bar soil nails during the ground investigation stage would be a realistic way of progressing a design if the use of hollow bars is being considered for the working nails. In this way the actual pull-out resistance of the nails from different soiltypes across a site would be determined before the design stage, with the soil nail lengths being optimised during the design based on actual pull-put data instead of theoretical working bonds and overburden pressures. This would remove some of the reliance of the design on pull-out testing during construction of hollow bar working nails, with a reduced number of pull-out tests being required during construction.

Published literature (Cadden et al 2011) details different methods of hollow bar nail installation before testing but these methods involve complicated plant and operations which requires skilled work and specialist plant and it may be impractical on sites where a large number of nails are to be installed and tested. However, the above study does highlight the difficulties the industry around the world is experiencing trying to determine an appropriate testing method for hollow bar soil nails.

In order to improve the testing process of self-drilled hollow bar nails it may be better to test shorter grouted nail lengths only which correspond to the design bonded lengths, i.e. grouting the passive zone of the nail into the soil type expected for the production nail bond length. This approach would depend on the bonded length assumed or calculated in the design and on the local soil conditions. However, testing of a sufficient number of nails of different bonded lengths in each expected soil material and analysing the results in terms of 'cautious estimate' (BS EN 
1997: 2009) of bond resistance (per metre bonded length or for the nail assuming cylindrical bond) would decrease the potential errors and provide, at least statistical, evidence of validity of the design assumptions. In this case, a better control of the actual grouted length and grout quantities would be needed bearing in mind the potential grout permeation within the adjacent soil. In our case the grout intake could not be controlled for each nails due to the fact that grout pumps on site provided grout to several nails that were installed concurrently across the slope. To avoid the need for the above, the hole could be progressed using a traditional method of drilling, with or without casing, and installing the nail tendon after a set amount of grout has been placed in the distal end of the hole. If a solid bar is used in this process, providing the hole diameter is the same as for the hollow bar nail, a packer could be also installed which will improve the control of bonded length while producing results on the bond strength comparable to hollow bar nail. With this approach, the installation and testing time will be shortened (one nail vs short-long nail pairs; shorter bond length would mean smaller testing setup and shorter testing time) which can be of great benefit where an already failed or unstable slope is to be stabilised in an area of high risk. Additionally, this approach can potentially provide an opportunity to correlate the bond strength of traditionally installed solid bar nails and self-drilling hollow bar nails, recognised as a common design problem (Cadden et al 2010).

From this case study, it became apparent that both the designer and the contractor need to consider the wider aspects of nail testing and be flexible during the construction process. The designer had to consider the access to test nail locations and balance the testing schedule against the potential outcomes of the testing, while the contractor had to be flexible to match the installation and testing techniques to the requirements of the design specification (Mickovski et al 2013). In the future, the designer and contractor could benefit from additional detail on selfdrilled hollow bar nails installation and testing in the current codes of practice as suggested previously in the literature (Cadden et al 2010). Empirical results from case studies could be collated to form basis of Best Available Techniques document covering all aspects of self-drilled hollow bar soil nail testing from scoping to interpretation of results.

\section{Conclusions}

A number of installation and testing methods for hollow bar soil nails were tried with variable success as part of a slope stabilisation project in Scotland. The hollow bar nails were quicker to install than the solid bar nails and their use could save time and labour on the project. The most time consuming part of the process was the preparation for testing which involved excavation of large volumes of soil and disturbance to the slope. The test setup was dictated by the testing method and the bonded length of the nail which ultimately affected the success of the test. The LN/SN method proved sufficient for verification of the design assumptions in the half of the tests, the other half of the tests being inconclusive (the design did not fail but the intepretation of the results was impossible) due to the encountered ground conditions and the assumptions that had to be made for this method. To verify the design for the inconclusive results, additional 
investigations using different installation methods were employed. The additional investigation tests focussing on determining the strength of the bonded length were more successful although there was a variation in the resulting values of bond strength.

The potential for optimisation of the design lies in more detailed testing prior and during the construction as well as adoption and verification of a bond resistance approach. To do this, it is suggested to use solid bar nails for testing, provided the diameter is the same as for the working nails, where only the bonded length of the nail is pulled out having successfully been separated from the rest of the nail with a packer. Current design codes and codes of practice should be updated to include testing methods applicable to hollow bar self drilled nails and partial factors of safety specific to hollow bar self drilled nails based on empirical results and further research.

\section{Acknowledgements}

The help of Mr Alasdair MacArthur (Jacobs) and Mr Stuart Andrew (Aberdeenshire Council) with testing supervision and reporting is greatly appreciated. We thank Kimberly Wray of Innovivid for the support with the graphics preparation for publishing.

\section{References}

BS 8006-2 (2011) Code of practice for strengthened/reinforced soils. Part 2: Soil nail design. BSI, London, UK.

BS EN 14490 (2010) Execution of special geotechnical works - Soil nailing. BSI, London, UK.

BS EN 1991 (2009) Eurocode 1 - Actions on structures. BSI, London, UK.

BS EN 1997-1 (2007) Eurocode 7 - Geotechnical Design Part 1 - General rules. BSI, London, UK.

Cadden A W, Gómez J E, Baxter A C, Bird T 2010 Hollow Bar Soil Nails Pullout Test Program. Report no. FHWA-CFL/TD-10-001, Federal Highway Administration, U.S. Department of Transportation, Lakewood, CO., USA.

DSI (Dywidag Systems International) (2008) DYWI Drill Hollow Bar. Dywidag Systems International. Brisbane, Australia.

DMRB HA 68/94 (1994) Design Manual for Roads and Bridges. Design Methods for the Reinforcement of Highway Slopes by Reinforced Soil and Soil Nailing Techniques. The Scottish Office Industry Department.

Frank R and Zhao S R (1982) Estimation par les paramètres pressiométriques de 
l'enfoncement sous charge axiale des pieux forés dans les sols fins, Bull. liaison Labo

P. et Ch., n 119, mai-juin 1982, pp. 17-24.

GEO (Geotechnical Engineering Office) (2008) Geoguide 7: Guide to soil nail design and construction. The Government of the Hong Kong Special Administrative Region, Kowloon, Hong Kong, 97pp.

Gómez J E, Filz G M, Ebeling R M, Dove J E (2008) Sand-to-Concrete Interface Response to Complex Load Paths in a Large Displacement Shear Box, ASTM Geotechnical Testing Journal. 31(4): 14-29.

Kutschke W G, Tarquinio F S, Petersen W K (2007) Practical soil nail wall design and constructability issues. In: Proceedings DFl's 32nd Annual Conference on Deep Foundations Colorado Springs, Colorado, October 11-13, 2007. Deep Foundation Institute, Colorado Springs, Co., USA.

Lazarte C A (2011) Proposed specifications for LRFD soil-nailing design and construction. National Cooperative Highway Research Program, Report 701. Transportation Research Board, Washington, D.C., USA.

Lazarte C A, Elias V, Espinoza R D, Sabatini P J (2003) Geotechnical Engineering Circular no.7: Soil nail walls. Federal Highway Administration , U.S. Department of Transportation Washington, D.C., USA

Littlejohn G S and Bruce D A (1977) Rock anchors state of the art. Foundation Publication LTD.

Mickovski S B. Black J D, Smith M J (2013) Innovative use of ECC (NEC3) for procurement and management of infrastructure projects with limited funding: Bervie Braes case study In: Proc. 29th Annual ARCOM Conference, 2-4 September 2013, Reading, UK, eds. S.D. Smith \& D.D. Ahiaga-Dagbui, Association of Researchers in Construction Management, 799-808.

Mickovski S B (2014) Resilient design of landslip prevention measures: a case study. Accepted for publication in Proceedings of ICE: Forensic Engineering, Special Issue on defining hazards from climate change for resilient design.

Mickovski SB (2014) Stabilisation of former trunk road embankment using combined structural and eco-engineering strategies. In: Proc. 3rd Int'I Conf. on road and rail infrastructure CETRA 2014, Split Croatia, 28-30 April 2014. 
Murray R T (1993) Development of specifications for soil nailing. Research Report RR380, Transport Research Laboratory, London, UK.

Norris J E, Stokes A. Mickovski S B,Cammeraat E, van Beek R, Nicoll B C, Achim A (Eds.) (2008) Slope Stability and Erosion Control: Ecotechnological Solutions, Springer, pp 290.

Phear, A, Dew, C, Ozsoy, B, Wharmby, N J, Judge, J, Barley, A D (2005). Soil nailing - best practice guidance. C637, CIRIA, London, UK.

Porterfield, J A, Cotton D M, Byrne P E R (1994) Soil nailing field inspectors manual - soil nail walls. Office of Technology Applications, Federal Highway Administration, Publication FHWASA-93-068, Washington D.C., USA.122pp.

Richards T D (2010) Thoughts on Soil Nail Testing and Design. In: R. Finno,; Y.M.A. Hashash, and P. Arduino (eds) Earth Retention Conference 3. ASCE. pp. 229-235.

Samtani, N C and Nowatzki, P E (2006) Hollow-core soil nails state-of-the-art practice. US Department of Transportation, Federal Highways Administration Office of Bridge Technology, April 2006, pp 55. 


\section{Figure captions}

Figure 1 Schematic representation of bonded/debonded section of a test nail divided by a packer or bond isolator. This arrangement allows pullout testing of the bonded length of the test nail which lies in the passive zone of the slope.

Figure 2 a) Site location plan. b) Typical geo-morphological logical cross section showing the soil nail design. The soil nailing works (testing and production nails) were carried out on the lower slope only.

Figure 3 Test nail installation using a) ROC 460 rig and b) KR 960 rig. The access, safety and stability were ensured using a steel rope and winch anchored at the road level.

Figure 4 A schematic of the 'Long nail / Short nail' (LN/SN) testing system. The nails in the pair have to be installed in close proximity of each other to minimise the potential of variation in the soil properties but apart enough as to avoid interaction during testing.

Figure 5 Test setup for the pullout testing of sacrificial nails. a) excavation (long and short nails can be seen) b) testing frame installation on one of the nails of the pair $c$ ) pullout testing while recording pullout force and displacement.

Figure 1 Typical pullout behaviour of a) long (full line) and short (dashed line) nail of a pair (TN20). b) ATN (full line; ATN12) and KLEMM (dashed line, KLEMM 7) nail. Bonded lengths can be seen in Tables 1 and 2 .

Figure 7 Bond pullout stress for a) LN/SN tests; b) Investigation tests 
Table 1. Results of the pullout tests on LN/SN testing system. The resistance to pullout of the grouted short nail length is subtracted from the one of the long nail to derive the resistance of the bonded length. Remarks: N/A and $\left(^{*}\right)$ denote inconclusive tests where the short nail pulled out at a higher load than the long nail or short nail pulled out at a relatively high load in relation to the design yield strength of the steel bar i.e. where the interpretation of the result was difficult due to the nature of the test; $\left(^{* *}\right)$ denotes design verification failure. GSG = Glacial Sands and Gravels, GT = Glacial Till.

\begin{tabular}{|c|c|c|c|c|c|c|c|}
\hline Test nail & $\begin{array}{c}\text { Grouted } \\
\text { length of } \\
\text { short nail } \\
{[\mathrm{m}]}\end{array}$ & $\begin{array}{l}\text { Pullout } \\
\text { resistance } \\
\text { of short } \\
\text { nail }[\mathrm{kN}]\end{array}$ & $\begin{array}{c}\text { Additional } \\
\text { grouted } \\
\text { length of } \\
\text { long nail } \\
\text { [m] }\end{array}$ & $\begin{array}{c}\text { Pullout } \\
\text { resistance } \\
\text { of long nail } \\
{[\mathrm{kN}]}\end{array}$ & $\begin{array}{c}\text { Pullout } \\
\text { resistance } \\
\text { of bonded } \\
\text { length [kN] }\end{array}$ & $\begin{array}{l}\text { Bonding } \\
\text { Strata }\end{array}$ & Remarks \\
\hline TN11 & 8.8 & 340 & 11.2 & not tested & & GSG \& GT & N/A \\
\hline TN13 & 7.6 & 310 & 9.4 & 360 & 50 & GSG \& GT & $\star \star$ \\
\hline TN14 & 8.6 & 210 & 11.4 & 360 & 150 & GSG \& GT & * \\
\hline TN15 & 8.2 & 100 & 11.8 & 160 & 60 & GSG \& GT & $\star \star$ \\
\hline TN16 & 8 & 290 & 10 & 350 & 60 & GSG \& GT & ** \\
\hline TN17 & 8.6 & 90 & 11.4 & 250 & 160 & GSG \& GT & \\
\hline TN18 & 12.2 & 290 & 11.8 & not tested & & GT & $N / A$ \\
\hline TN19 & 13 & 260 & 11 & 140 & & GSG \& GT & ** \\
\hline TN20 & 10 & 150 & 14 & 310 & 160 & GT & \\
\hline TN21 & 11.8 & 300 & 12.2 & 280 & & GT & ** \\
\hline TN22 & 9.2 & 360 & 8.8 & 360 & & GSG \& GT & * \\
\hline TN23 & 11.2 & 190 & 12.8 & 340 & 150 & GT & \\
\hline TN24 & 12.4 & 290 & 11.6 & 360 & 70 & GSG \& GT & * \\
\hline TN34 & 10 & 80 & 2 & 350 & 270 & GT & \\
\hline TN35 & 5.25 & 40 & 4.75 & 360 & 320 & GSG & \\
\hline TN25 & 6 & 220 & 9 & 360 & 140 & GT & * \\
\hline TN26 & 10 & 360 & 2 & 360 & & GT & * \\
\hline TN28 & 10 & 360 & 2 & not tested & & GT & N/A \\
\hline TN29 & 3 & 30 & 7 & 130 & 100 & GT & \\
\hline TN31 & 6 & 80 & 9 & 360 & 280 & GT & * \\
\hline TN32 & 4 & 130 & 6 & 180 & 50 & GSS \& GT & \\
\hline TN51 & 9 & 30 & 2 & 190 & 160 & GSG \& GT & \\
\hline TN52 & 9 & 80 & 2 & 120 & 40 & GT & ** \\
\hline TN53 & 5.5 & 70 & 1.5 & 170 & 100 & GSG & \\
\hline TN54 & 9 & 140 & 2 & 250 & 110 & GT & \\
\hline TN55 & 5.25 & 40 & 1.75 & 110 & 70 & GSG & \\
\hline TN56 & 9 & 130 & 2 & 290 & 160 & GSG \& GT & \\
\hline TN57 & 5 & 70 & 2 & 120 & 50 & GSG & \\
\hline
\end{tabular}


Table 2 Results of the investigation tests. Remarks: $\left(^{*}\right)$ denotes inconclusive tests where the design load $\leq$ pullout load $\leq$ combined test load, i.e. where the interpretation of the result was difficult due to the nature of the test; $\left(^{* \star}\right)$ denotes design verification failure. GSG = Glacial Sands and Gravels, GT = Glacial Till.

\begin{tabular}{|c|c|c|c|c|c|c|}
\hline Test nail & $\begin{array}{l}\text { Installed } \\
\text { length } \\
{[\mathrm{m}]}\end{array}$ & $\begin{array}{l}\text { Bonded } \\
\text { length } \\
\text { [m] }\end{array}$ & $\begin{array}{l}\text { Failure } \\
\text { Load [kN] }\end{array}$ & $\begin{array}{l}\text { Design } \\
\text { Verification } \\
\text { Load (kN) }\end{array}$ & $\begin{array}{l}\text { Bonding } \\
\text { Strata }\end{array}$ & Remarks \\
\hline TN12 & 20 & 5.5 & 120 & 180 & GSG \& GT & * \\
\hline ATN10 & 20 & 9.7 & 155 & 155 & GSG \& GT & \\
\hline ATN11 & 20 & 9.7 & 230 & 165 & GSG \& GT & \\
\hline ATN12 & 20 & 9.7 & 150 & 150 & GSG \& GT & \\
\hline ATN14 & 20 & 5.5 & 70 & 180 & GSG \& GT & ** \\
\hline ATN5 & 13.5 & 5.5 & 220 & 195 & GT & \\
\hline ATN7 & 24 & 8.3 & 140 & 195 & GT & * \\
\hline ATN8 & 15 & 8.3 & 300 & 130 & GSG \& GT & \\
\hline ATN13 & 24 & 6.9 & 210 & 205 & GSG \& GT & \\
\hline TN27 & 15 & 2.8 & 55 & 80 & GT & $*$ \\
\hline TN30 & 15 & 2.8 & 45 & 80 & GT & ** \\
\hline ATN1 & 12 & 5.5 & 70 & 70 & GT & \\
\hline ATN3 & 15 & 2.8 & 35 & 110 & GT & ** \\
\hline ATN9 & 11 & 7.5 & 220 & 60 & GT & \\
\hline KLEMM1 & 24 & 5.5 & 70 & N/A & GT & \\
\hline KLEMM2 & 24 & 5.5 & 80 & N/A & GT & \\
\hline KLEMM3 & 24 & 6.9 & 110 & N/A & GT & \\
\hline KLEMM4 & 21 & 2 & 190 & N/A & GT & \\
\hline KLEMM5 & 18 & 2 & 80 & N/A & GT & \\
\hline KLEMM6 & 15 & 2 & 90 & N/A & GT & \\
\hline KLEMM7 & 12 & 2 & 80 & N/A & GT & \\
\hline & & & & & & \\
\hline
\end{tabular}




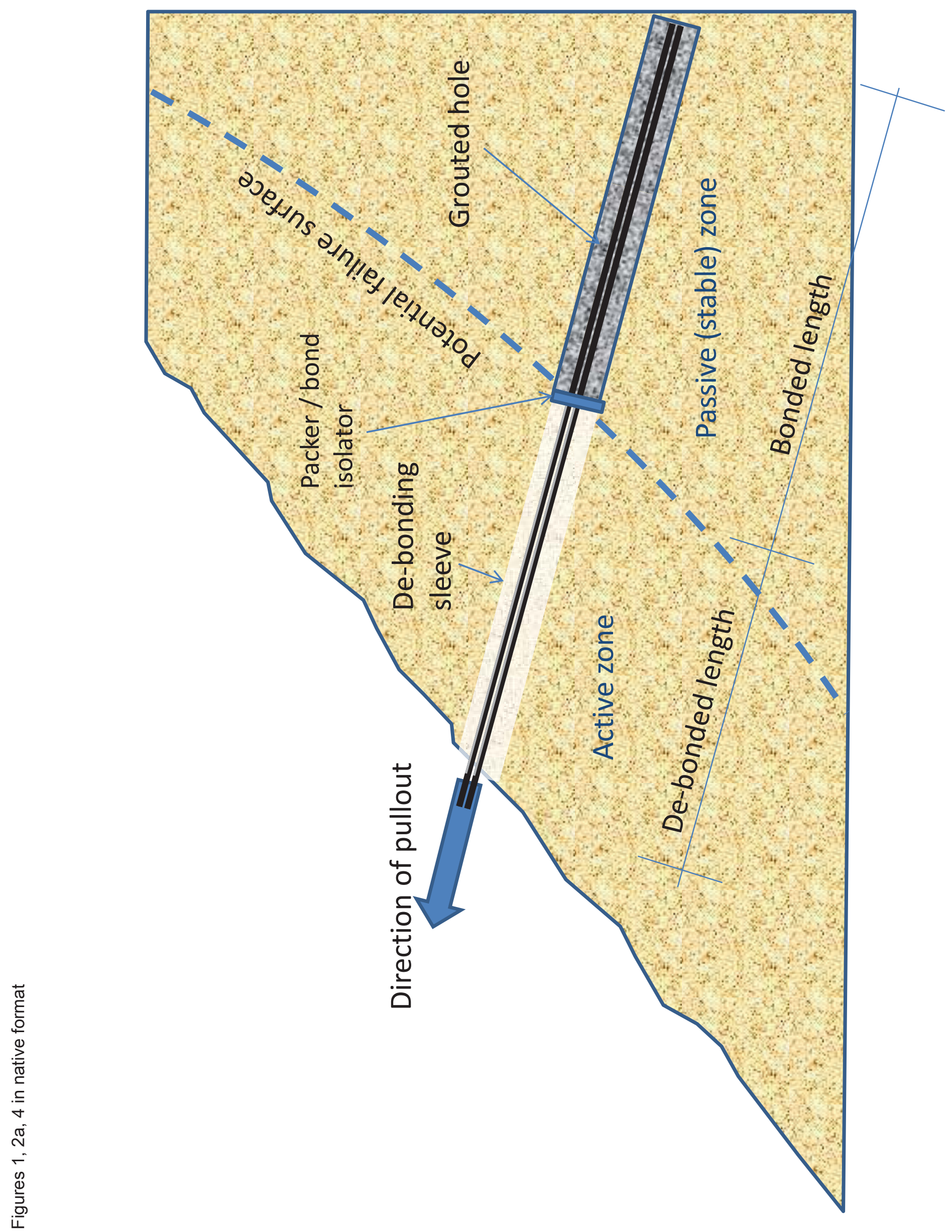




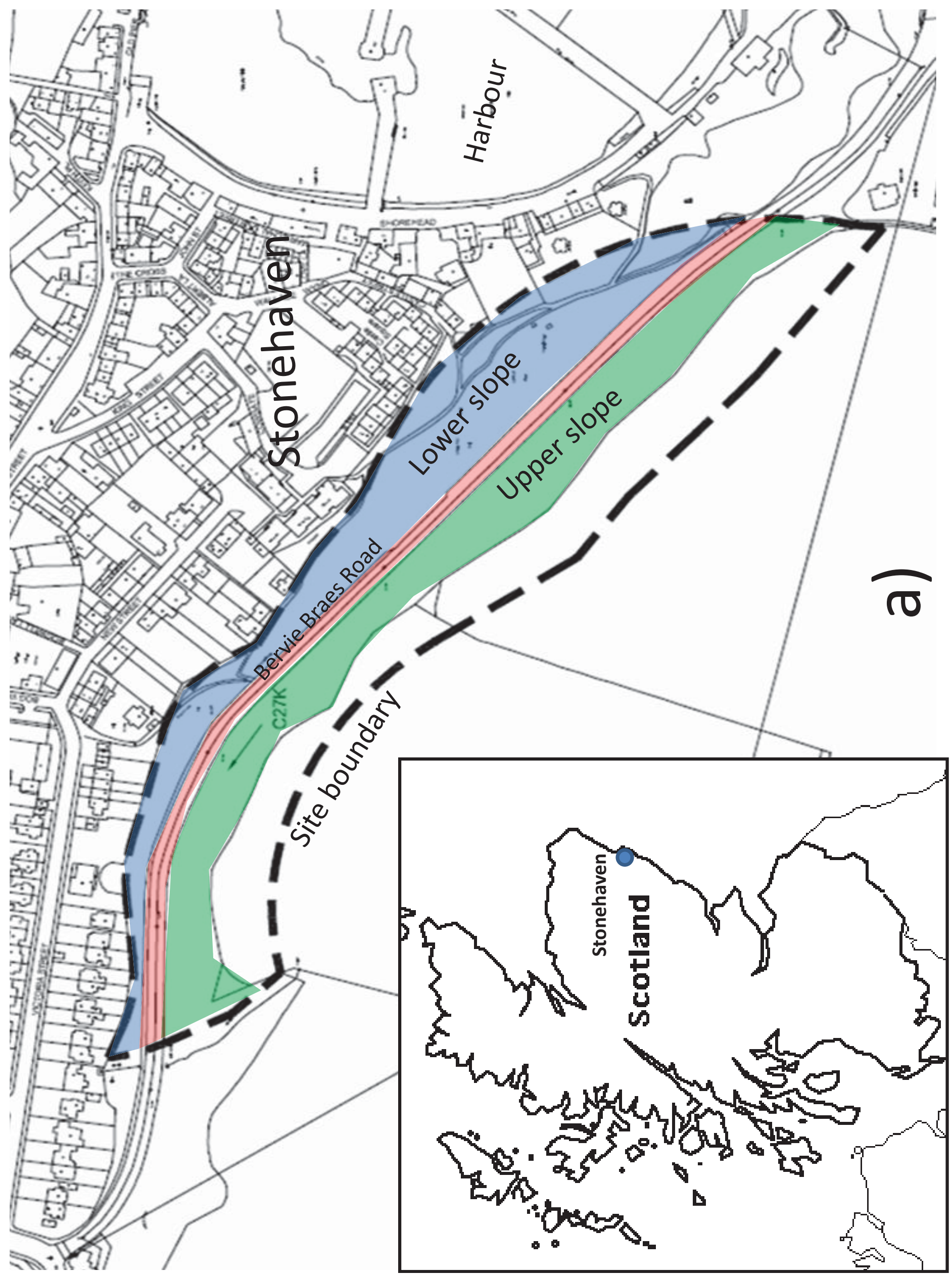




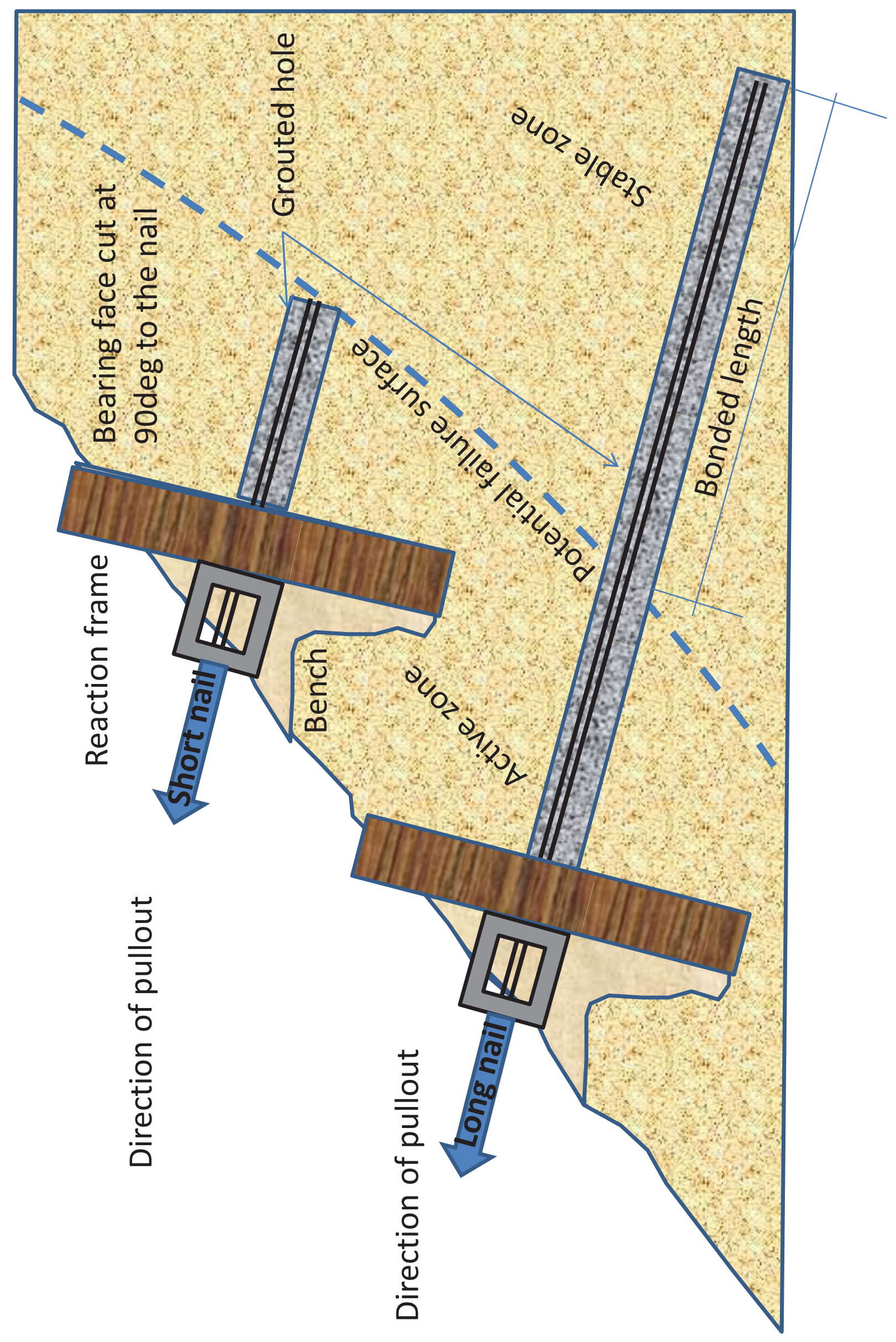




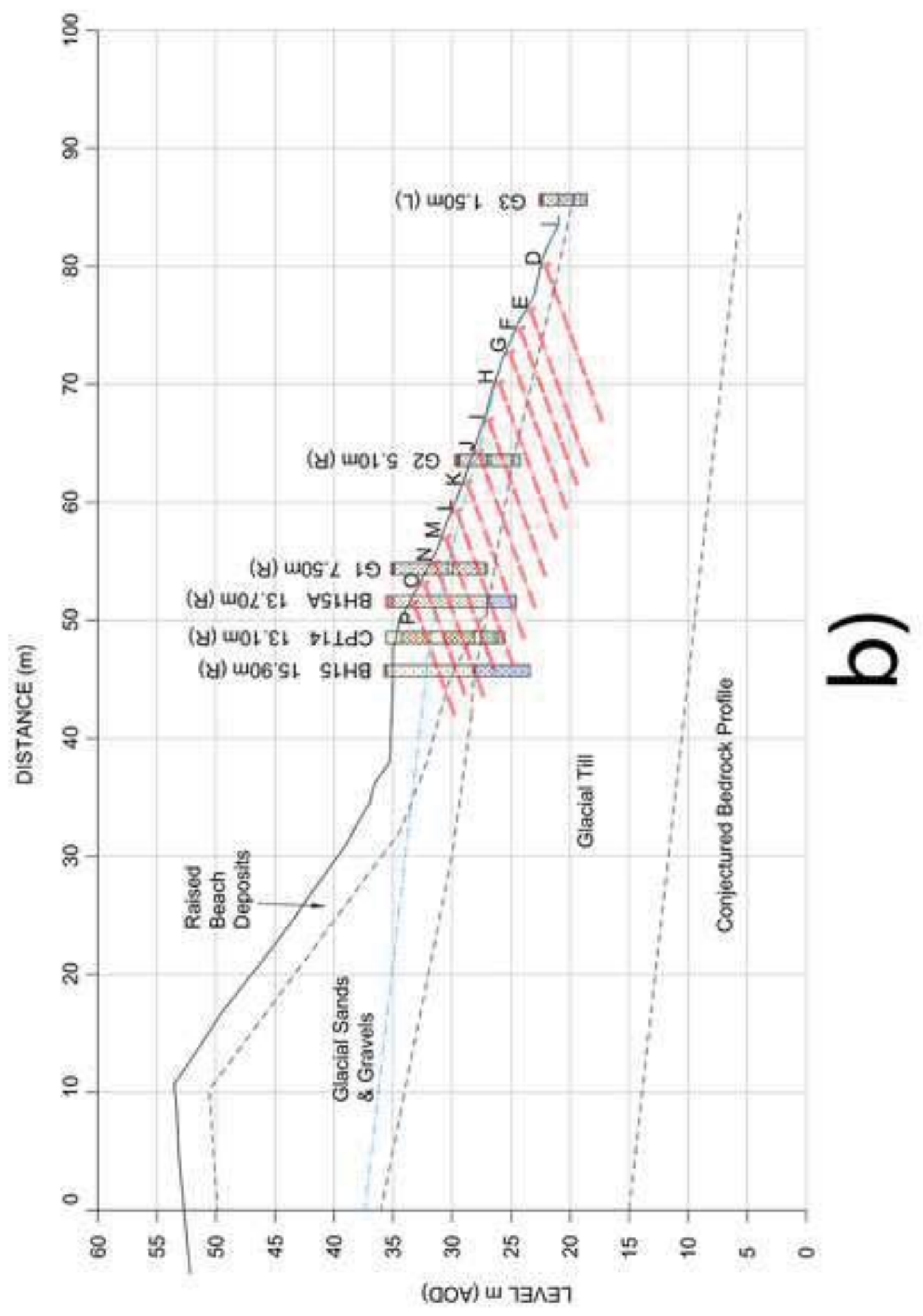

$\stackrel{0}{N}$
$\stackrel{0}{\overline{7}}$
믄 

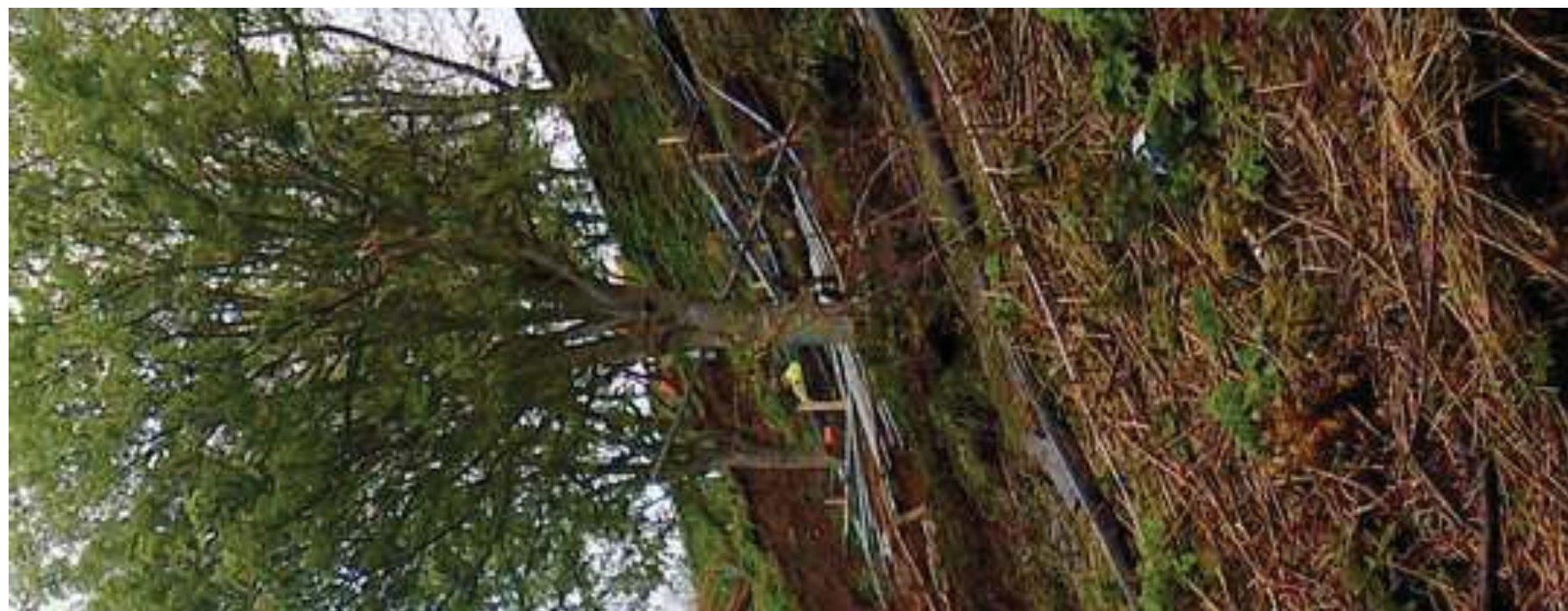

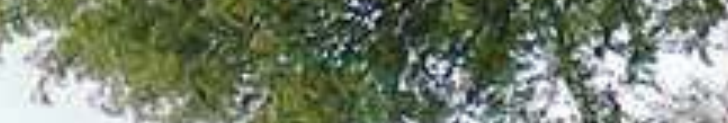

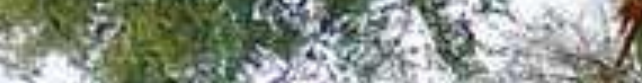

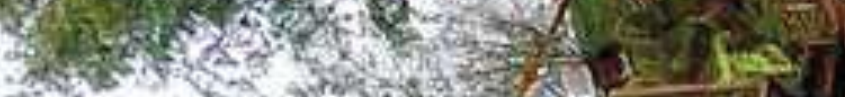
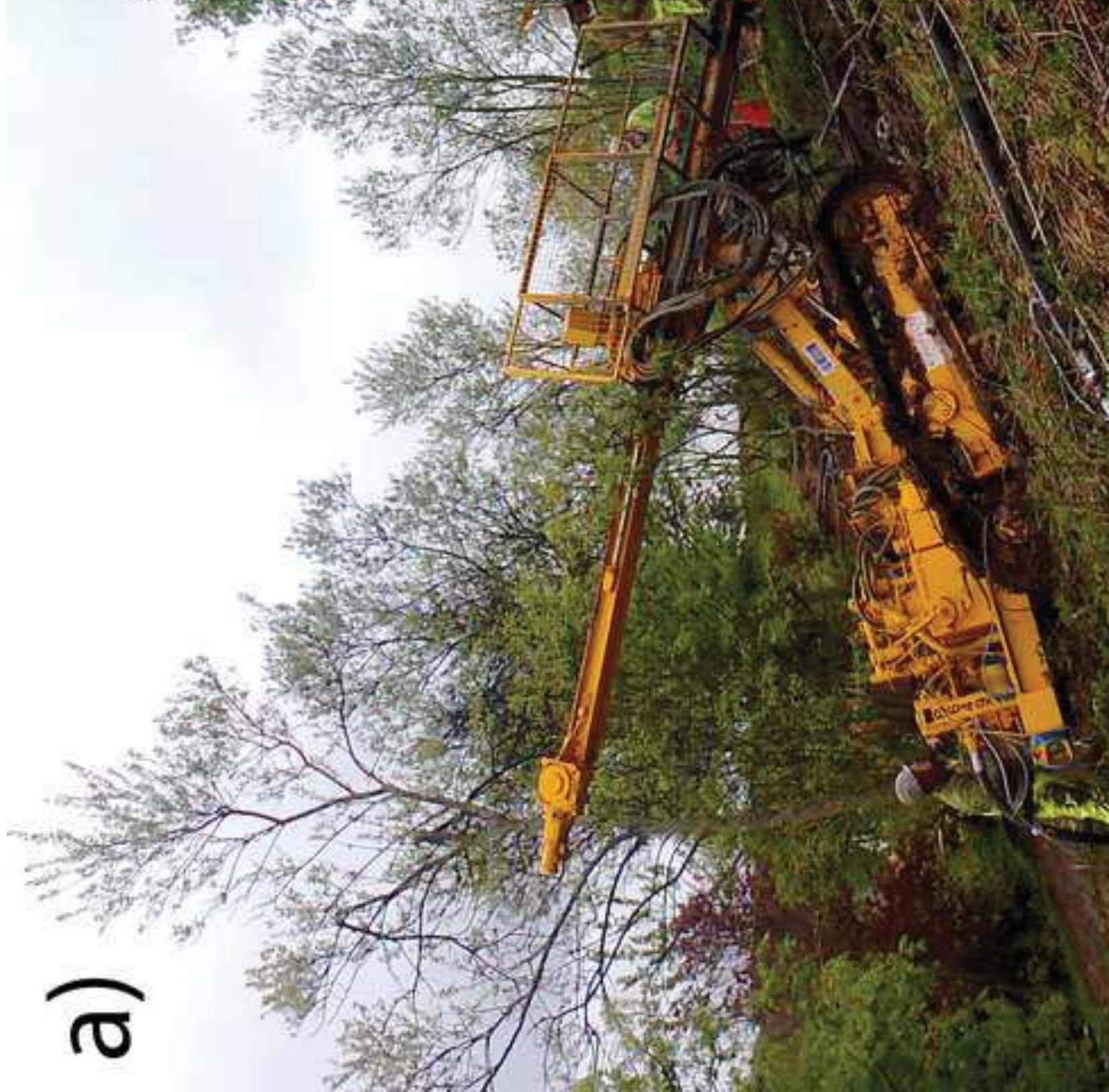

siogen

onstin
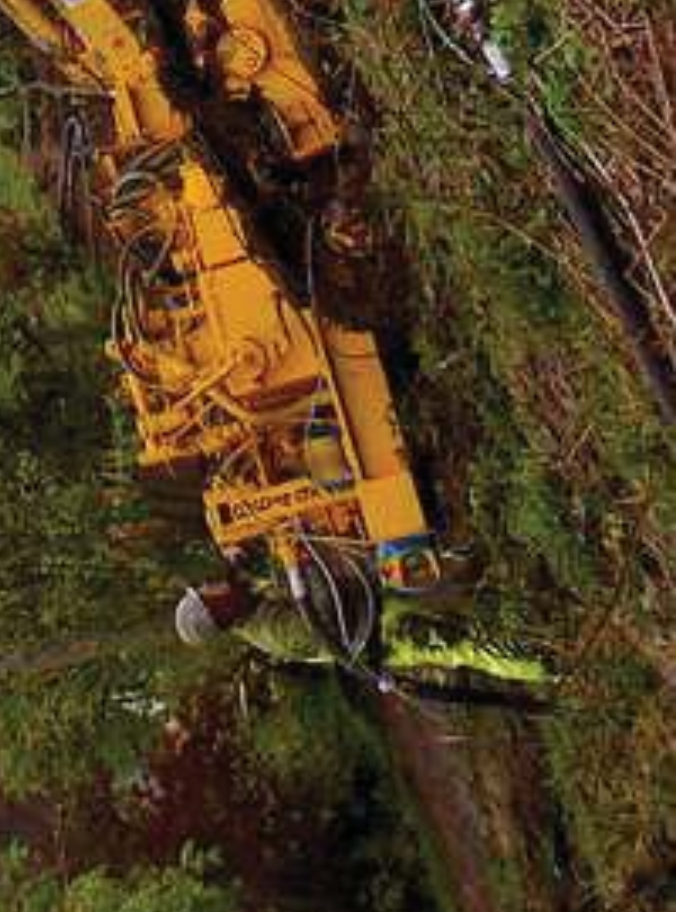

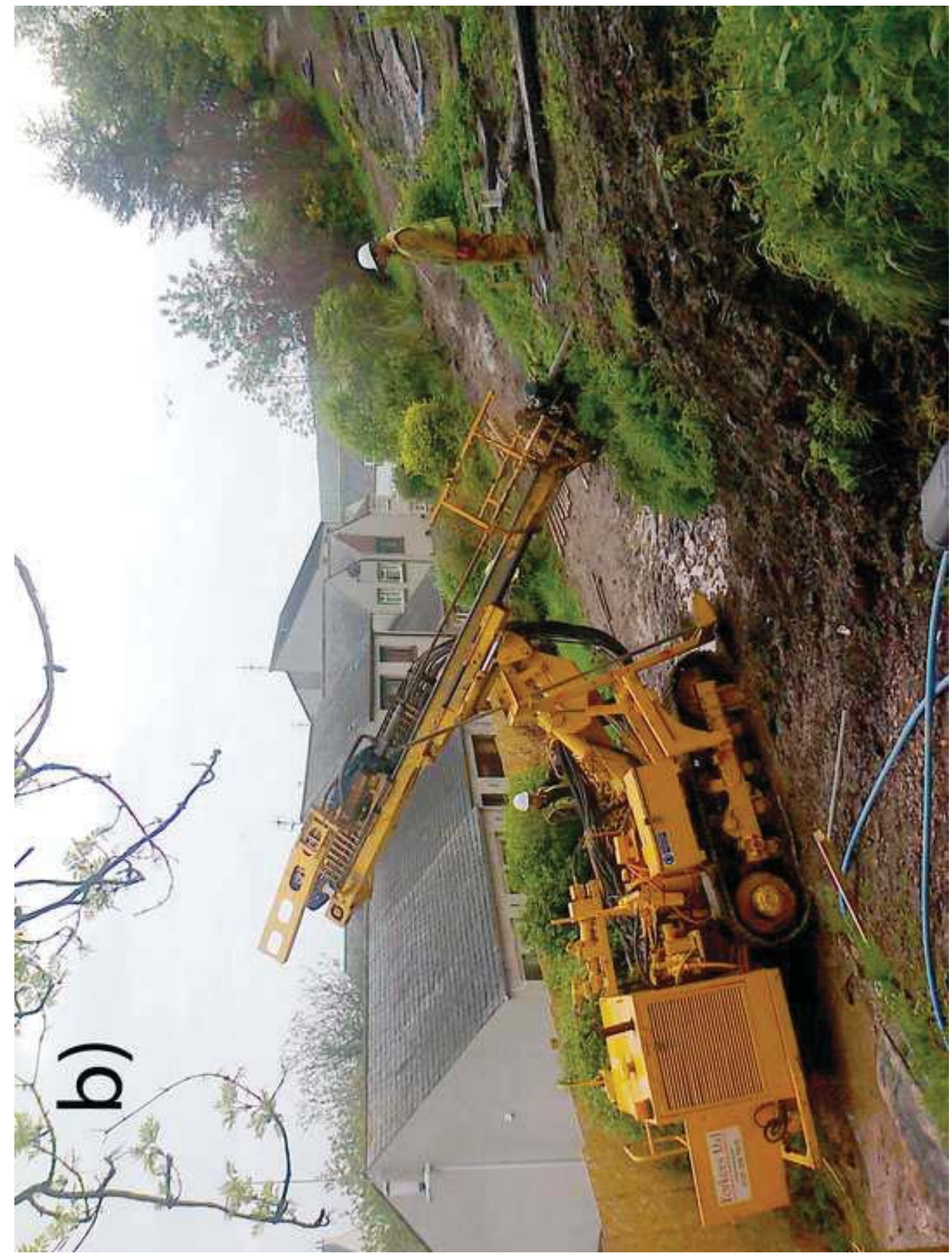

H. 


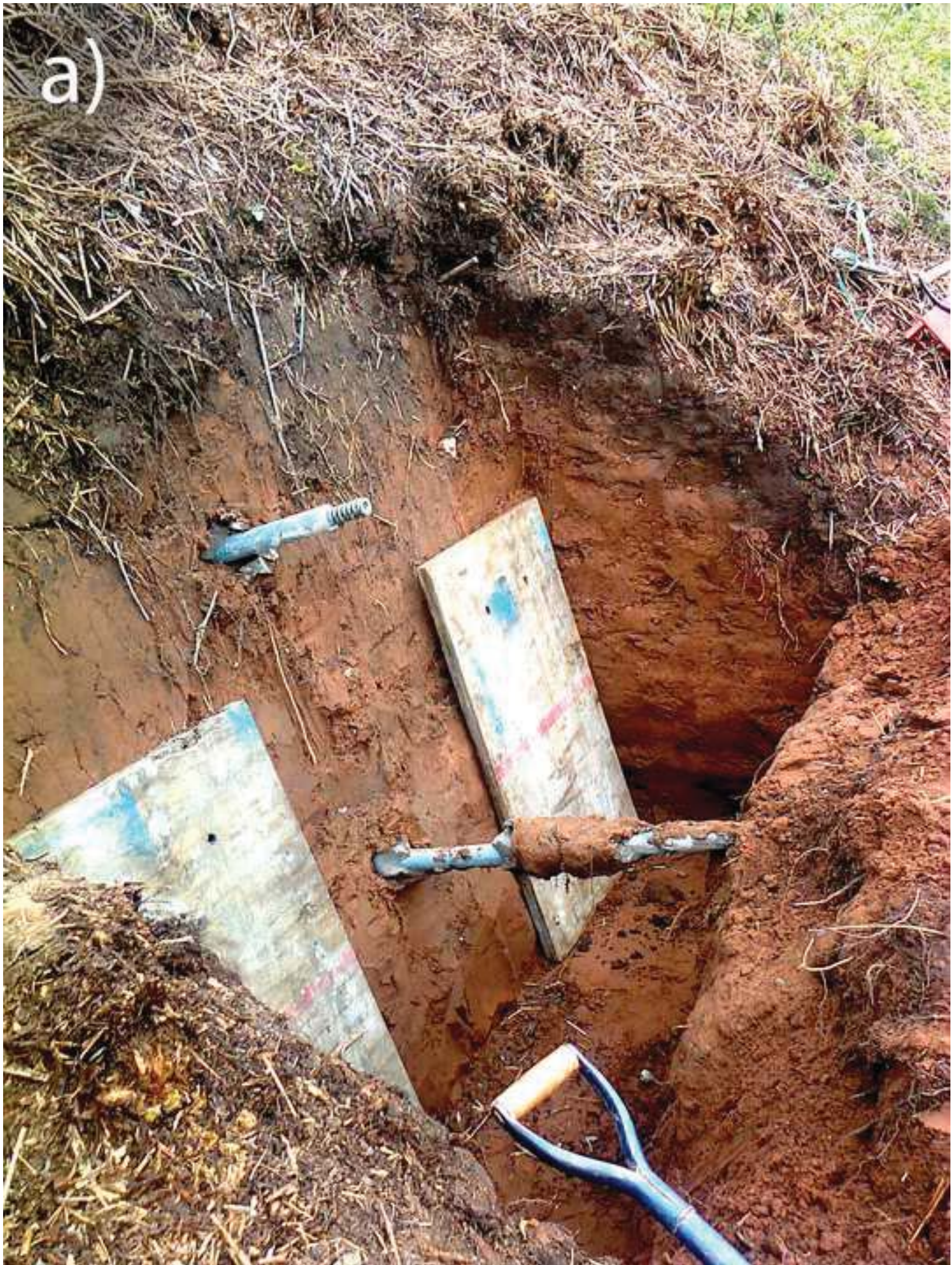




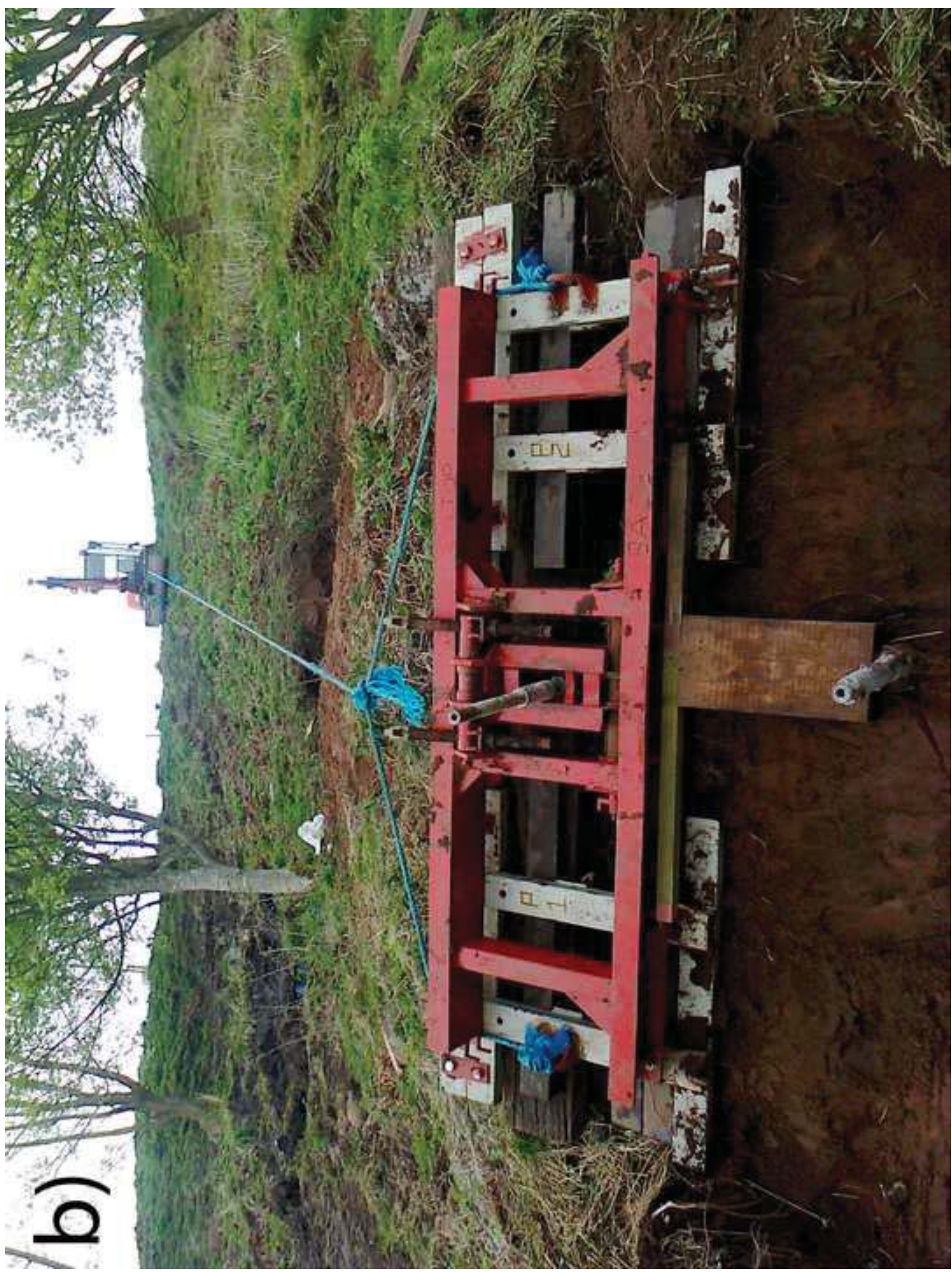




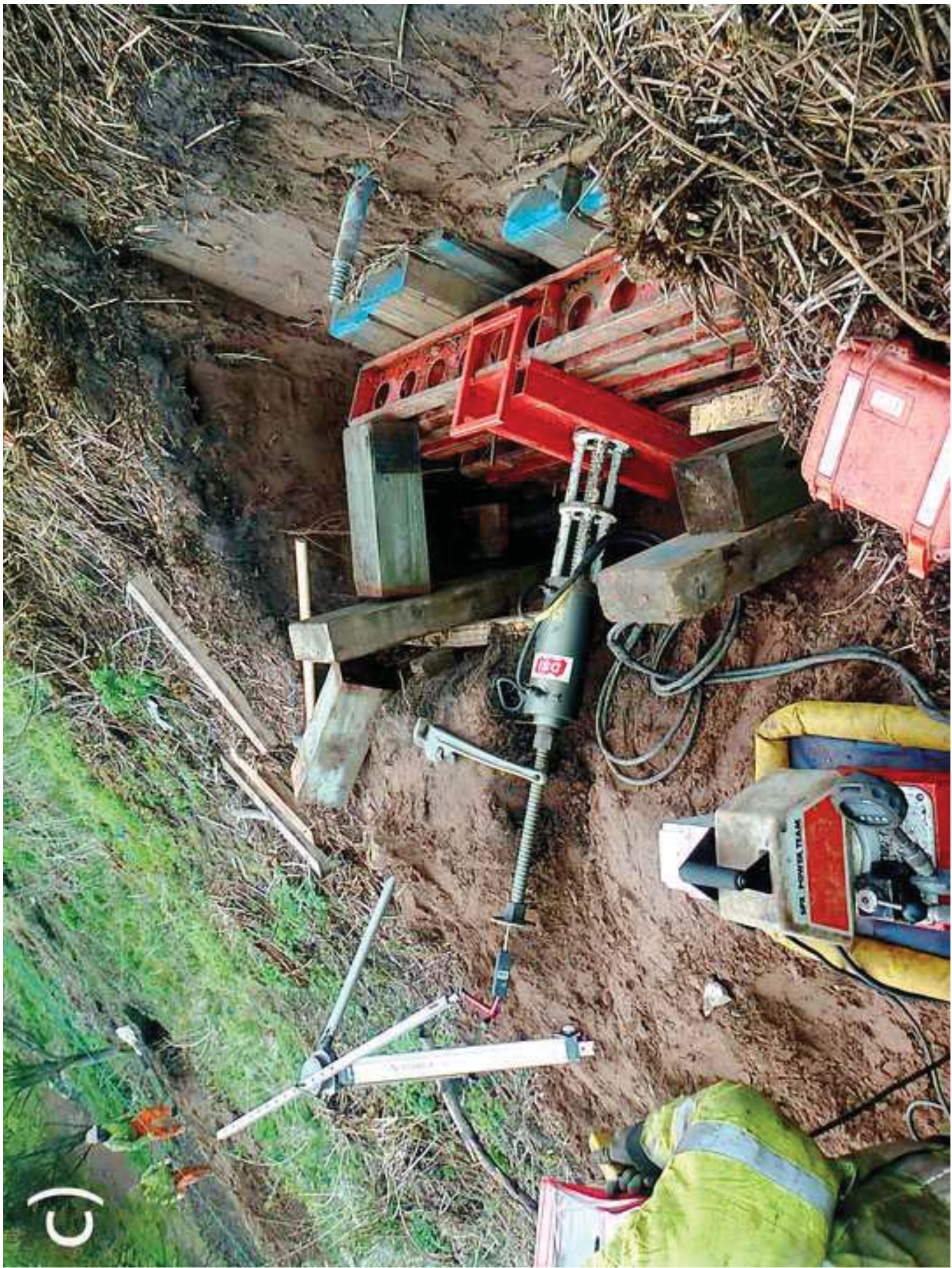




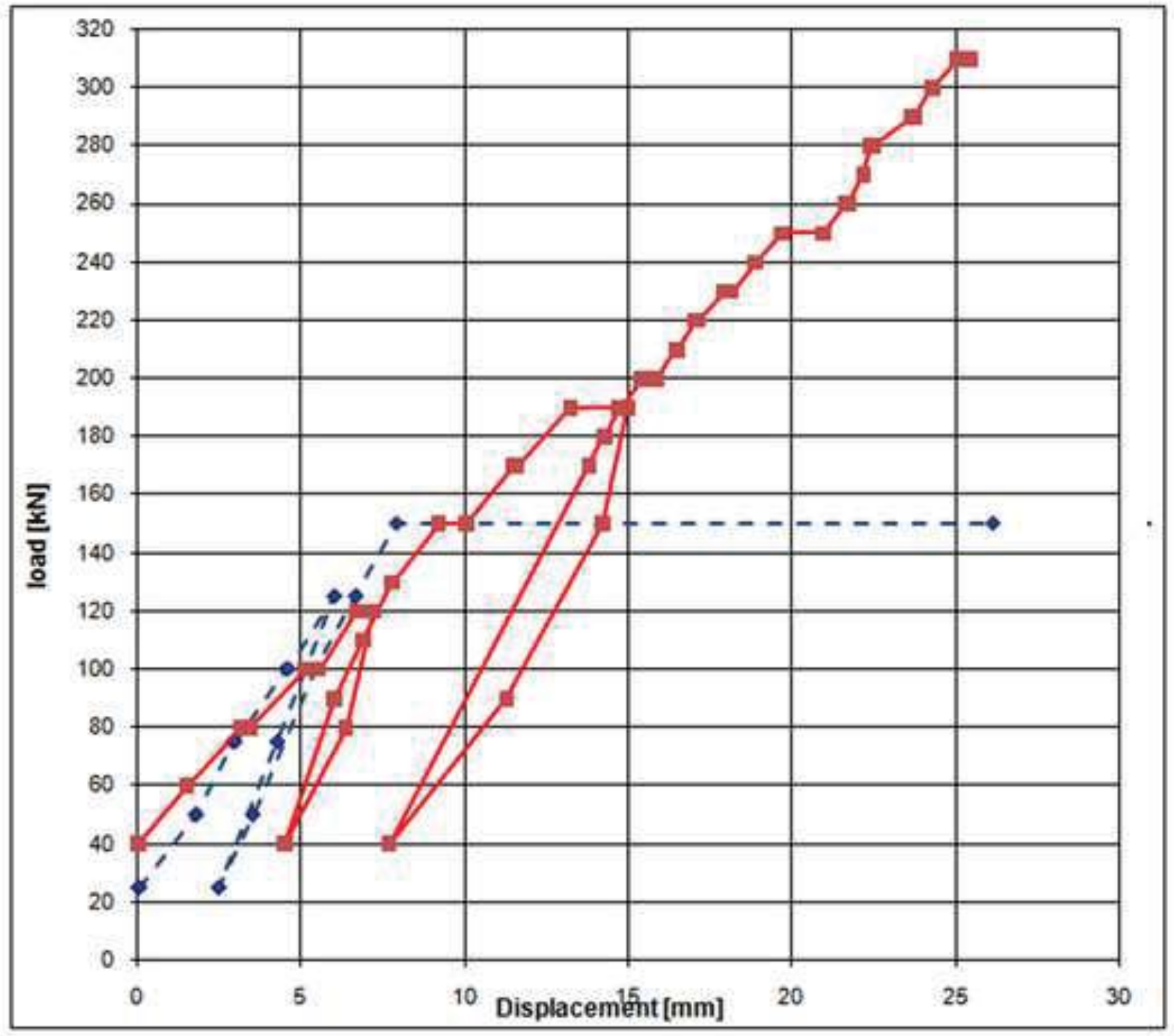




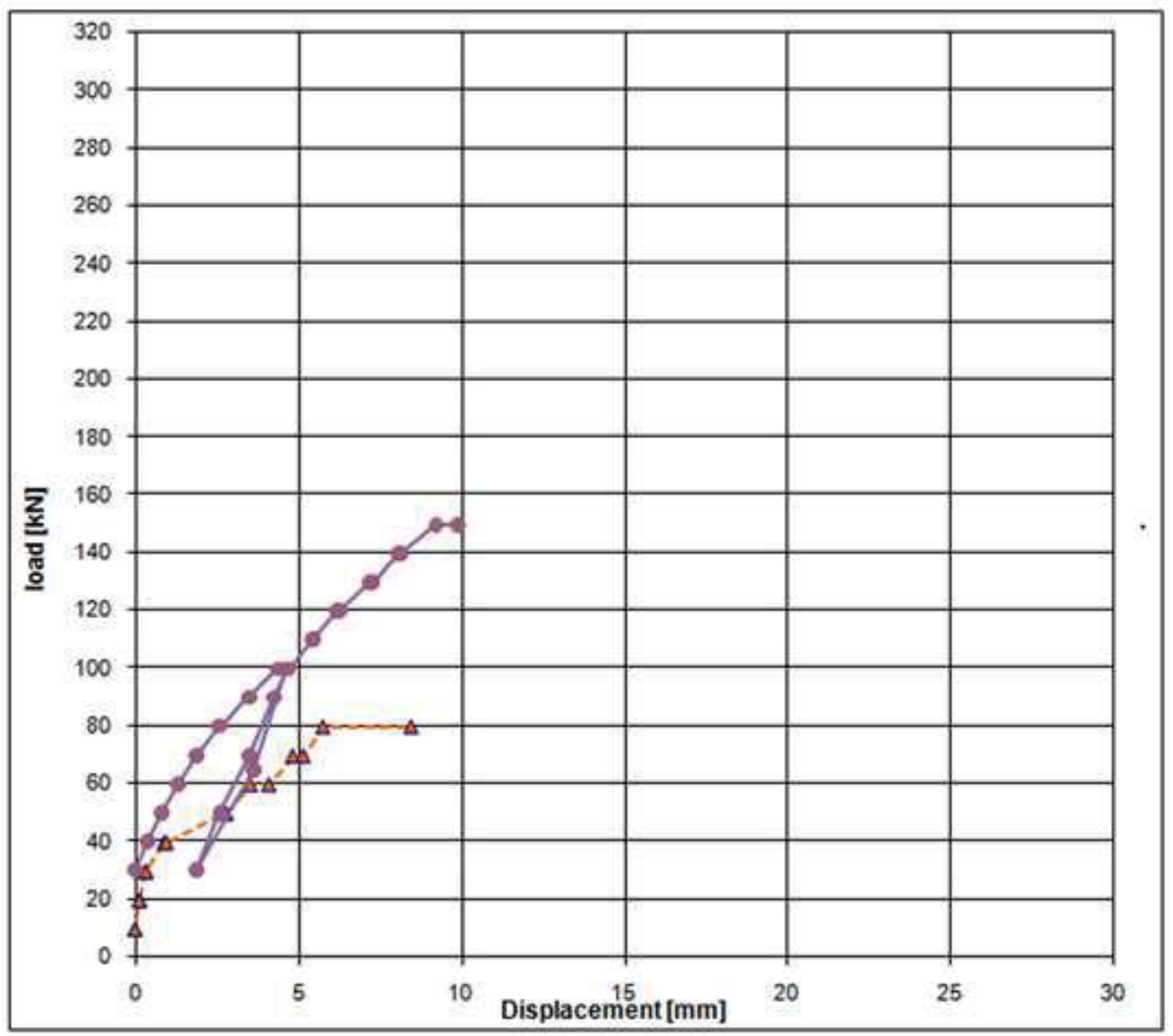




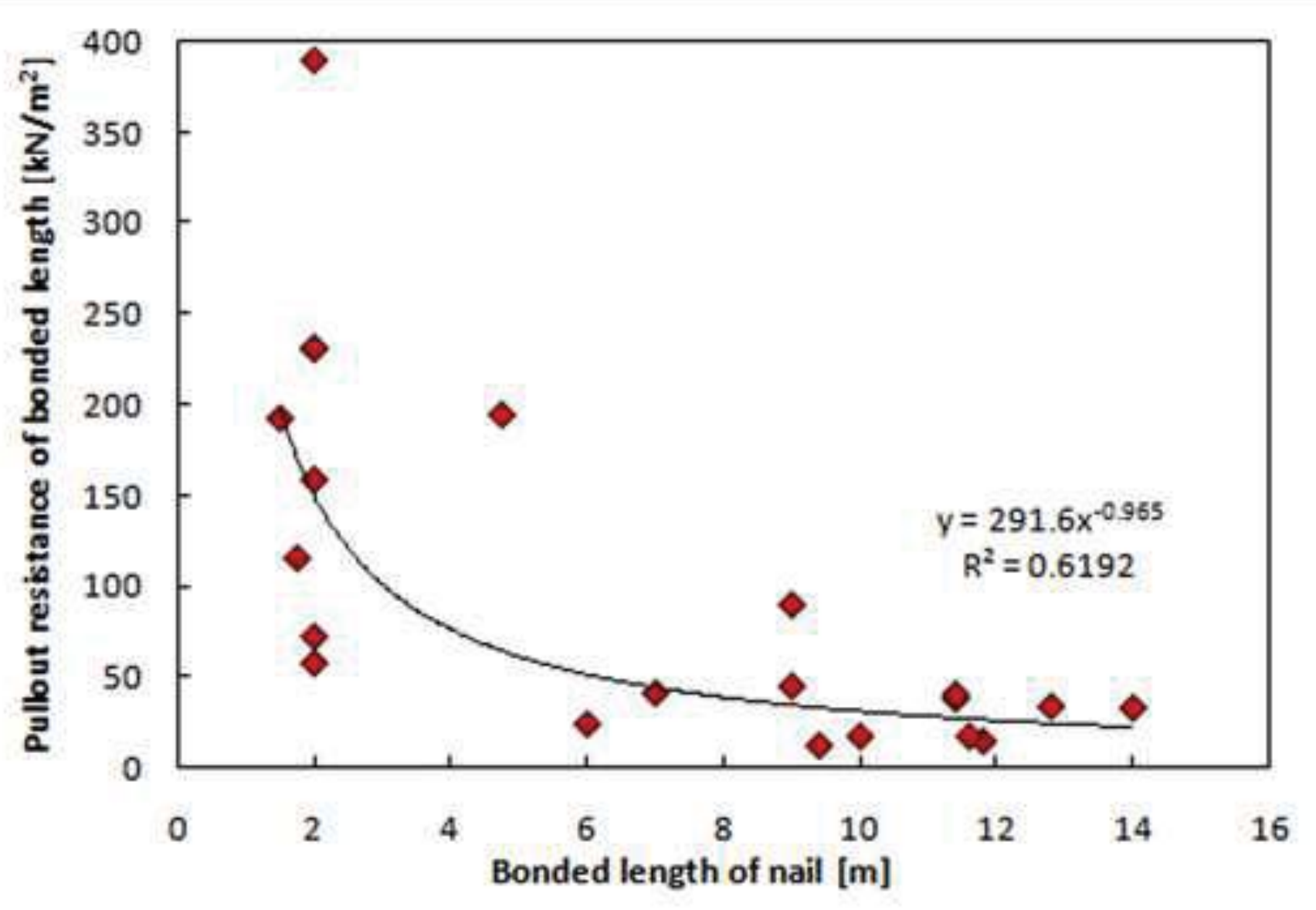




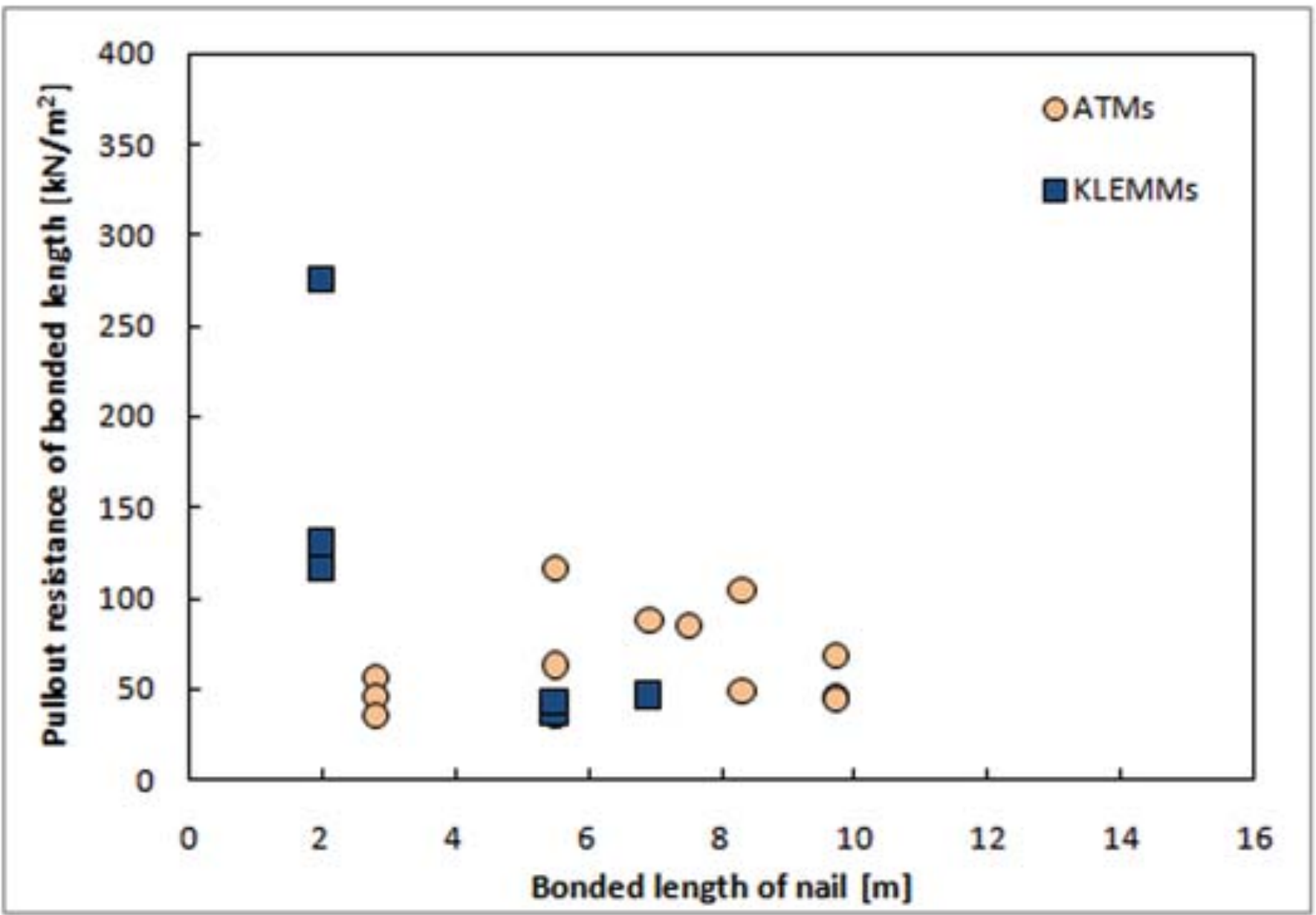

